This is the final peer-reviewed accepted manuscript of:

Tzankova, I., Prati, G., Eckstein, K., Noack, P., Amnå, E., Motti-Stefanidi, F., Macek, P., \& Cicognani, E. (2020). Adolescents' patterns of citizenship orientations and correlated contextual variables: Results from a two-wave study in five European countries. Youth \& Society, 1-24. Advance online publication.

The final published version is available online at: https://doi.org/10.1177/0044118X20942256

Rights / License:

The terms and conditions for the reuse of this version of the manuscript are specified in the publishing policy. For all terms of use and more information see the publisher's website. 


\section{Adolescents' Patterns of Citizenship Orientations and Correlated Contextual Variables: Results from a Two-Wave Study in Five European Countries}

Iana Tzankova

Corresponding author. Department of Psychology, University of Bologna, Piazza Aldo Moro 90, 47521 Cesena, Italy. ORCID: https://orcid.org/0000-0001-7172-2009

E-mail: iana.tzankova2@unibo.it

Gabriele Prati

Department of Psychology, University of Bologna, Piazza Aldo Moro 90, 47521 Cesena, Italy.

ORCID: https://orcid.org/0000-0002-0749-183X

Katharina Eckstein

Department of Educational Psychology, Friedrich-Schiller-University Jena, Humboldtstr. 27, 07743 Jena, Germany. ORCID: https://orcid.org/0000-0003-2603-763X

Peter Noack

Department of Educational Psychology, Friedrich-Schiller-University Jena, Humboldtstr. 27, 07743 Jena, Germany.

Erik Amnå

School of Humanities, Education and Social Sciences, Örebro University, Fakultetsgatan 1, 70182 Örebro, Sweden. ORCID: https://orcid.org/0000-0001-8311-0982

Frosso Motti-Stefanidi

Department of Psychology, National and Kapodistrian University of Athens, Panepistimiopoli, 15784 Athens, Greece.

Petr Macek

This item was downloaded from IRIS Università di Bologna (https://cris.unibo.it/)

When citing, please refer to the published version. 
Faculty of Social Studies, Masaryk University, Joštova 218/10, 60200 Brno, Czech Republic.

ORCID: https://orcid.org/0000-0002-6977-5811

\section{Elvira Cicognani}

Department of Psychology, University of Bologna, Piazza Aldo Moro 90, 47521 Cesena, Italy.

ORCID: https://orcid.org/0000-0002-8653-290X

\section{Acknowledgments}

The research reported in this paper was funded by the European Union, Horizon 2020 Programme, Constructing AcTive CitizensHip with European Youth: Policies, Practices, Challenges and Solutions (www.catcheyou.eu), grant agreement number 649538. The views and opinions expressed in this publication are the sole responsibility of the author(s) and do not necessarily reflect the views of the European Commission.

\section{Data availability statement}

The data that support the findings of this study are openly available from AMS Acta Institutional Research Repository - University of Bologna at http://doi.org/10.6092/unibo/amsacta/6420. This data is made available for open access in compliance with H2020 Program regulation, following the guidelines stipulated by the Data Management Plan adopted by the CATCH-EyoU research project.

\section{Disclosure statement}

The authors have declared that no competing interests exist. 


\begin{abstract}
Studies on youth participation tend to characterize youth as either active and trustful or as passive and alienated. This cross-national and longitudinal study examines patterns of citizenship orientations characterized by both manifest and latent involvement differentiated by one's position toward institutional politics (trustful or distrustful) among 1914 adolescents from five European countries $\left(53.5 \%\right.$ female; $\left.M_{A G E}=16.27\right)$. Demographic and proximal contextual correlates associated with different orientations at a one-year interval were also assessed.

Latent profile analysis identified four groups of citizenship orientations among adolescents: engaged trustful, engaged distrustful, unengaged trustful, unengaged distrustful. Differences of membership likelihood were found for background characteristics (gender and family income), school characteristics (track, democratic climate, student participation and its perceived quality), family and peer norms of participation.
\end{abstract}

Keywords: youth participation, political trust, civic development, proximal contexts, personcentered analysis 


\section{Adolescents' Patterns of Citizenship Orientations and Correlated Contextual Variables:}

\section{Results from a Two-Wave Study in Five European Countries}

Numerous contributions to civic and political participation have evidenced the need to acknowledge contemporary tendencies toward non-institutionalized forms of engagement among youth (Dalton, 2004; Harris et al., 2010; Loader et al., 2014; Zukin et al., 2006) and the multifaceted nature of citizens' relationship with the public sphere, including different forms of non-participation (Amnå \& Ekman, 2014; Ekman \& Amnå, 2012; Dahl et al., 2018). Several authors have argued that low levels of civic and political activity are not necessarily indicative of complete disengagement, but could be accompanied by latent involvement in societal affairs stemming from a standby or monitorial attitude (Amnå \& Ekman, 2014; Ekman \& Amnå, 2012; Evans \& Stoker, 2016; Schudson, 1996, 2006). In this line, Amnå and Ekman (2014) have underlined the existence of different forms of passivity and considered that it is important to investigate a standby involvement, characterized by interest in civic and political matters and readiness for participation. The authors examined empirically different forms of passivity among youth and identified four groups: active, who score high on both political participation and interest; standby, who score average on participation and high on interest; unengaged, who score low on both participation and interest; and disillusioned, who score the lowest on both indicators. Latent involvement is assumed to be accompanied by a sense of lack of urgency to actions, which derives from the trust put in institutions and their representatives to do their work. The standby citizens take an observational passive stand as long as they do not perceive the need for political action to be imperative, but they exhibit attentiveness and efficacy associated with politics. In this sense, they would be the "product of 'too well' functioning democracies" (Amnå \& Ekman, 2015, p. 106). 


\section{The Different Faces of Participation: Trustful and Critical Citizens}

Other authors, however, point out that distrust in politicians and institutions may also be accompanied by a need of critical supervision of the political process and an urge to take action to improve it (Dalton \& Welzel, 2014; Hibbing \& Theiss-Morse, 2002; Norris, 1999; Rosanvallon, 2008). In such a conception, critical citizens are seen as a resource for democracy and an indicator of its health, as they are assumed to also be motivated to monitor and control the political process (Dalton, 2004; Norris, 1999). A study conducted by Geissel (2008) explored the distinction between democratic citizens on dimensions of political attentiveness and satisfaction and identified both attentive-satisfied and attentive-dissatisfied groups, as well as inattentive-satisfied and inattentivedissatisfied groups. The author's findings indicate that attentive citizens are equally likely to uphold democracy-promoting attitudes and to participate, regardless of their political satisfaction. Moreover, it has been argued that disaffection with institutions in terms of lack of trust is conceptually and empirically distinguished from either political disengagement and powerlessness (i.e., lack of interest or internal efficacy), political estrangement (i.e., feeling of not belonging) or principle-driven dissatisfaction (i.e., anti-democratic orientation; Torcal \& Montero, 2006; Abdelzadeh \& Ekman, 2012).

The existing research suggests that there is a complex relationship between political trust and sociopolitical participation. For example, Hooghe and Marien (2013) have shown that the impact of political trust on participation varies according to the type of activity and to levels of political efficacy.

With these considerations in mind, we suggest that trust in the political process may characterize different orientations to participation among youth. The perception of unresponsive or opaque governance may characterize withdrawal from the political sphere or, conversely, critical involvement in the face of injustices in the system. 


\section{Contextual Characteristics of Civic Development}

Late adolescence is a particularly critical period for the development of sociopolitical orientations (e.g., Erikson, 1968; Sears \& Levy, 2003; Wilkenfeld et al., 2010; Youniss et al., 2002). Research in this context has often focused on different contexts that can provide opportunities for the growth of participatory capacity and behaviors. In particular, in line with contextual models of human development (Bronfenbrenner \& Morris, 2007), scholars have underlined that adolescents' civic sense and political attitudes are influenced by multiple environments — such as family and peers, with whom most social interactions take place; or schools and neighborhoods, where youth spend most of their daily lives.

\section{Social Norms on Participation}

Existing research has illustrated the fundamental role of families and peers on adolescents' civic development in providing opportunities for discussion and learning, as well as models of citizenship (e.g., Andolina et al., 2003; Rossi et al., 2016; Zaff et al., 2008). As the primary caregiving environment, the family introduces social norms and expectations (Kelly, 2006). During adolescence, peer groups also become very influential for political socialization (Allen \& Bang, 2015; Silbiger, 1977). Social norms favoring participation (e.g., peers and family members that hold positive attitudes toward participation) have been found to be relevant for adolescents' civic development (e.g., Glynn et al., 2009; Quintelier et al., 2012; Šerek \& Machackova, 2015).

\section{School Climate and Participation}

Research has shown that political attitudes and behaviors are promoted by a democratic school climate, in which students feel they can discuss topics openly and take part in decisionmaking at school (Flanagan et al., 2007; Quintelier \& Hooghe, 2013; Torney-Purta, 2002; Vieno et al., 2005). Moreover, students who perceive school climate as centered around democratic values tend to show higher trust in other people and in institutions (Hahn, 1998). The perception of fair 
treatment at school has also been linked to civic responsibility and engagement (Lenzi et al., 2014). The feeling of being treated fairly generally brings to consider authority as more trustworthy (Tyler \& Smith, 1999).

Experiences in school can provide opportunities for participation and reflection in a supportive and challenging environment, which has also been shown to lead to positive development of civic and political attitudes (Fernandes-Jesus et al., 2012; Ferreira et al., 2012). For instance, research on service learning has evidenced that critical reflection during the experience is essential to reach positive impact and avoid detrimental effects (Chupp \& Joseph, 2010; Roschelle et al., 2000). Focusing on the quality of participation experiences (Ferreira et al., 2012) stresses the importance of settings that allow the consideration and integration of plural diverse perspectives for the social development of adolescents.

\section{Sense of Neighborhood Community}

The neighborhood is another social setting that has been demonstrated to influence civic development (Atkins \& Hart, 2003). Neighborhood social resources and the perception of social connectedness have been linked to greater participation among adolescents (Albanesi et al., 2007; Lenzi et al., 2013; Rossi et al., 2016). The subjective experience of community-i.e., sense of community — has also been identified as having a central role in facilitating participation (Cicognani \& Zani, 2015). Neighborhood, in this sense, is conceived as a learning context that can provide adolescents with possibilities to exercise rights and responsibilities as members of the local community and foster interest and engagement on a broader civic and political level.

\section{The Present Study}

The present study addresses gaps in the youth participation literature in a twofold manner. Firstly, we examine patterns of citizenship orientations through a person-centered analysis, demonstrating the combinations of levels of involvement and positions toward institutional politics 
that can be identified among a population of late adolescents in five European countries. We argue that young citizens can be defined not only as engaged or unengaged, but they can simultaneously be distinguished between trustful and distrustful (Tzankova, 2018). Political and societal interest are considered crucial in characterizing youth who are involved latently (Ekman \& Amnå, 2012) and are considered to be important groundwork for future participation (Prior, 2010; Russo \& Stattin, 2017; Wanders et al., 2020). However, few studies have examined empirically typologies of youth citizenship defined by active participation and interest (Amnå \& Ekman, 2014) and none, to our knowledge, have expanded them by including a dimension of trust or have analyzed them in multinational samples. Thus, the patterns of youth involvement in our analysis are identified by three indicators: 1) activity in civic and political participation, which was expected to distinguish between active and inactive youth; 2) political and social interest, which was expected to distinguish between latently involved and uninvolved youth; 3) trust in institutions and in the political processes, which was expected to differentiate between trustful and distrustful attitude toward the political process (Gamson, 1968; Dahl et al., 2016). We expect to be able to identify up to six groups of adolescents with different combinations of involvement and political trust, distinguishing between: those that are engaged latently and/or actively in a trustful manner, those that are engaged latently and/or actively in a distrustful manner, those that are unengaged while trusting institutions and those that are unengaged and distrustful (i.e., alienated).

Secondly, our analysis seeks to investigate the demographic and proximal contextual correlates that are associated with different citizenship orientations at a one-year interval. Previous studies have mainly focused on predicting participation in different contexts and forms, and often through cross-sectional methods. However, to our knowledge, no study has analyzed the effect of both demographic and proximal contextual factors on citizenship orientations using a longitudinal design. In addition, the use of temporally separated measures reduces common method bias 
(Podsakoff et al., 2012). In particular, we examine how the emerging patterns of citizenship orientations can be characterized by gender, socio-economic and migrant background, as well as by family and peer norms of engagement, school characteristics (school track, perceived democratic climate, student participation and perceived quality of participation), and sense of neighborhood community. Based on the existing literature, it is likely that better socio-economic background, higher norms of participation, higher levels and quality of school participation and higher sense of neighborhood community are linked to profiles characterized by higher activity and interest in civic and political affairs. It is also possible to assume that the perception of democratic school climate is associated with trustful and active citizenship orientations.

\section{Method}

\section{Participants}

The data was collected in two waves distanced by a one-year interval (in 2016 and 2017) in five European countries - Italy, Sweden, Germany, Greece, and Czech Republic (Cicognani et al., 2020). Adolescents, aged between 14 and 19 years old, filled out a self-report questionnaire mostly on paper $(91.8 \%)$, as well as online $(8.2 \%)$. The study was approved by ethic committees in each country. The participants were approached in upper secondary schools from different school tracks (i.e., lower and higher).

The final sample consisted of 1914 participants (53.5\% were female; $46.1 \%$ were male; two participants indicated "Other" as their gender and six participants did not respond). The distribution across countries was as follows: 684 (35.7\%) from Italy, 221 (11.5\%) from Sweden, 235 (12.3\%) from Germany, 361 (18.9\%) from Greece, 413 (21.6\%) from the Czech Republic. The average age of the participants was 16.27 years old $(S D=.97)$. Students coming from a higher school track were $79.9 \%$ of the sample. Those with a migrant background - born abroad or with parents who were born abroad - were $22.2 \%$. 


\section{Measures}

\section{Independent Variables}

Demographics and other correlated independent variables, listed below, were all assessed at Time 1 of the study.

Demographic Information. Participants were asked to report their age, gender, parents' education level (measured by a mean score of father's and mother's completed level of education) and perceived family income ("Does the money your household has cover everything your family needs?”), as well as migrant background (participants born in another country or who had a parent born in another country were classified as migrant).

Peer and Family Norms of Participation. We used six items based on Šerek and Machackova (2015), measured on a 5-point Likert scale $(1=$ strongly disagree to $5=$ strongly agree). The degree to which participants' families supported participation was measured with three items ( $\alpha=.65$; e.g., "My family would approve it if I became politically active.”). Friends' normative support of engagement was measured with the same three items $(\alpha=.63)$.

Democratic School Climate. Perceived democratic school climate was assessed with seven items measured on a 5-point Likert scale $(1=$ strongly disagree to $5=$ strongly agree $)$. The items measured: open classroom climate (adapted from the IEA ICCS study; Schulz et al., 2010; e.g., "Teachers respect our opinions and encourage us to express our opinions during the classes"); school external efficacy (e.g., "Students at our school can influence how our school is run"); and perceived fairness of teachers and of the school's rules (two items from the Teacher and Classmate Support Scale; Torsheim et al., 2000; e.g., "Our teachers treat us fairly"). The reliability of the scale was very $\operatorname{good}(\alpha=.83)$.

Student Participation at School. Participants were asked whether in the past year they: had represented other students in student councils or in front of teachers or principals; had been active 
in a student group or club; had been active in a school sports group or club. Answers were dichotomous and a composite score was obtained by summing the three items (range 0-3).

School Quality of Participation. Quality of participation at school was measured by four items on a 5 -point Likert scale $(1=$ strongly disagree to $5=$ strongly agree $)$, corresponding to the dimension of reflection within the Quality of Participation Experiences Scale (Ferreira et al., 2012; e.g., "During that time, I have... observed conflicting opinions that brought up new ways of perceiving the issues in question."). The reliability of the scale was good $(\alpha=.76)$.

Sense of Community. Four items assessed participants' perceptions of opportunities present in their territorial community. These corresponded to two dimensions from the scale Sense of Community for Adolescents (Chiessi et al., 2010) - satisfaction of needs and opportunities for involvement, and opportunities for influence (e.g., "I think that people who live in our neighborhood could change things in the community."). The items were measured on a 5-point Likert scale $(1=$ strongly disagree to $5=$ strongly agree $)$. The reliability for the scale was good $(\alpha=$ $.76)$.

\section{Profile Indicators}

The following indicators used for the analysis of the patterns of citizenship orientations were assessed at Time 2 of the study.

Participation. Participation in civic and political activities in the last 12 months was measured on a 5 -point scale $(1=$ no to $5=$ very often $)$ with 18 items adapted from Barrett and Zani (2015). An example was "Volunteered or worked for a social cause". The reliability of the scale was very good $(\alpha=.81)$.

Political and Social Interest. Interest in politics, European and national politics, and societal issues was measured by four items on a 5 -point Likert scale $(1=$ strongly disagree to $5=$ strongly agree), adapted from Amnå et al. (2010). An example was "How interested are you in 
politics?". The reliability of the scale was very good $(\alpha=.84)$.

Political Trust. The attitude toward institutions and the political process was operationalized through a mean score of two items measuring trust in European and national institutions (e.g., "I trust the national government") and two items, adapted from Fischer and Kohr (2002), measuring political alienation (reversed scores; e.g., "It does not matter who wins the European elections, the interests of ordinary people do not matter"). All were measured on a 5-point Likert scale $(1=$ strongly disagree to $5=$ strongly agree $)$. The reliability was good $(\alpha=.74)$.

Principal axis factoring analysis was performed to confirm the construct validity of this measure. It extracted one factor that predicted $42.8 \%$ of the variance, with factor loadings ranging from .51 to .79 , indicating adequate validity.

\section{Analysis}

To identify the profiles that described the association between the chosen indicators, Latent Profile Analysis (LPA) was conducted using Mplus (Muthén \& Muthén, 2015). The choice of the number of profiles in LPA is informed by goodness-of-fit statistics, including information criteria and likelihood-based tests.

To evaluate the impact of correlates on the probability of being in one or the other latent profile, we employed a three-step approach, which does not require re-calculating estimations for the latent variables when including covariates or distal outcomes and takes account of a classification uncertainty rate (Asparouhov \& Muthén, 2014; Vermunt, 2010). We used the R3STEP command in Mplus which provides multinomial logistic regression results for the test of external predictors' effect on profile membership.

\section{Results}

The descriptive statistics of the latent profile indicator variables assessed at Time 2 and the correlated variables assessed at Time 1, as well as correlations between the variables are presented 
in Table 1 . The level of participation among respondents was generally rather low $(M=1.39, S D=$ 0.41) and the measure presented an elevated skewness.

[Table 1. Descriptive Statistics and Intercorrelations]

\section{Patterns of Citizenship Orientations}

Solutions from two to eight latent profiles were estimated and compared for fit and interpretability (see Table 2).

[Table 2. Model and Fit Statistics]

Bayesian Information Criterion (BIC) values were compared across solutions and these decreased for each additional class added. We considered the degree of decrement for each added class by identifying an "elbow" point (Nylund-Gibson \& Choi, 2018), which corresponded to the 4class solution. Given that the indicator of participation presented skewness and the Bootstrapped Parametric Likelihood Ratio Test (BLRT) $p$ value did not distinguish between solutions, we looked at the Adjusted Lo-Mendell-Rubin Likelihood Ratio (LMR) $p$ value to compare the fit between neighboring class models (see Nylund et al., 2007). The significant value for the 4-class solution and the insignificant value for the 5-class solution lend support to the choice of the 4-class solution. Moreover, solutions with more than four classes presented small classes with under $5 \%$ of the sample, which could compromise stability and did not add substantial interpretative information. Based on these considerations, the 4-class solution was selected as the most parsimonious and best representing the data.

The quality of the classification is summarized by the entropy measure that ranges from zero to one, where values close to one indicate good classification. While not high, entropy level was moderate for the 4-class solution $\left(E_{k}=.67\right.$, see Table 2$)$.

The model-estimated mean scores $(E M)$ for civic and political participation, sociopolitical interest and political trust for the four identified latent profiles are shown in Figure 1. The analysis 
identified a group, who showed above average participation $(E M=1.62)$, the highest interest $(E M=$ 4.00) and the highest political trust $(E M=3.57)$. This group was labeled as Engaged Trustful $(n=$ $195 ; 10.2 \%)$. Another group of youth also exhibited slightly higher than the average levels of participation $(E M=1.53)$ and higher interest $(E M=3.42)$, but lower political trust $(E M=2.07)-$ they were termed Engaged Distrustful ( $n=436 ; 22.8 \%)$. Almost half of youth in our sample was included in the Unengaged Trustful-named profile ( $n=934 ; 48.8 \%)$, who showed lower participation $(E M=1.31)$, lower interest $(E M=2.80)$ and high trust $(E M=3.22)$. Finally, the Unengaged Distrustful profile ( $n=349 ; 18.2 \%)$ was characterized by low levels of participation $(E M=1.26)$, very low level of interest $(E M=1.92)$ and low political trust $(E M=2.11)$.

\section{[Figure 1. Profiles of citizenship orientations at Time 2]}

\section{Demographic and Contextual Correlates}

The multinomial logistic model results, in terms of odds ratios, are presented in Table 3.

The results showed that Italian participants were more likely classified in the Engaged and Unengaged Distrustful groups and less likely in the Engaged Trustful group. German participants were more likely members in the Engaged Trustful profile, compared to Unengaged groups, as well as more likely Engaged Distrustful rather than Unengaged Distrustful. Greek adolescents were more likely in one of the Distrustful groups compared to Trustful ones.

Male participants with respect to females were less likely to be members of the Unengaged Trustful profile than any other. Participants whose family was better off were less likely to be in the Unengaged Distrustful profile compared to Trustful ones. Adolescents in higher track schools were also less likely to be members of the Unengaged Distrustful profile compared to Trustful ones. Parental education and migrant background did not show significant effects on membership.

Democratic school climate at Time 1 predicted the membership in different profiles at Time 2. Students who reported higher democratic school climate were more likely to be members of the 
Trustful profiles with respect to the Distrustful ones. Students who reported greater opportunities for critical reflection in their school, as well as students who reported greater participation at school at Time 1 were more likely to be members of the Engaged profiles than of the Unengaged ones at Time 2.

Participants who reported higher levels of peer norms of engagement at Time 1 were less likely classified as Unengaged Distrustful with respect to the Trustful groups at Time 2. Furthermore, the more participants reported that their family encouraged civic and political participation at Time 1, the more likely it was that they were members of the Engaged Trustful profile rather than of the Unengaged ones at Time 2. Moreover, they were more likely Engaged Distrustful rather than Unengaged Distrustful. Sense of neighborhood community did not have significant effects on the membership in different profiles.

[Table 3. Demographic and Contextual Correlates: Multinomial Logistic Regression Results (Odds Ratios)]

\section{Discussion}

The present research sought to examine cross-national patterns of adolescent citizenship orientations by means of a person-centered analysis and to explore the demographic and contextual correlates that are associated longitudinally with the adoption of different orientations. We have argued that, to contribute to the understanding of young people's variety of positions with respect to democratic citizenship, it is necessary to expand previous investigations of participation typologies beyond binary distinctions (e.g., "active vs. passive") that conceal the complexities of youth engagement (cf. Walsh et al., 2018; Dahl et al., 2018), to better capture psychological orientations and motivations underlying patterns of activity or inactivity. A novelty of the present study is that we investigated patterns of citizenship orientations by including both manifest and latent expressions of civic and political involvement, as well as orientations toward institutions and the 
political process. Another novelty of the proposed study is that we explored the effect of both demographic and proximal contextual factors on citizenship orientations using a longitudinal design.

The analysis identified four groups of orientations among adolescents from five European countries: engaged trustful, engaged distrustful, unengaged trustful, unengaged distrustful. Although active participation was generally low as expected from previous evidence of the levels of activity among teens (e.g., Schulz et al., 2010), the identification of two engaged profiles, corresponding to approximately a third of the sample, showed that a considerable number of adolescents displayed high civic and political attentiveness. The evidence provides support for the view that political and societal interest are crucial in characterizing latent orientations toward participation (Amnå \& Ekman, 2014). However, the results also showed that each of the groups with different levels of involvement — engaged and unengaged — could be further differentiated between trustful and distrustful based on their attitude toward institutions and the electoral process. Our results lend support for the idea that trust characterizes different orientations toward civic and political participation (Geissel, 2008). These findings highlight that for some youth political distrust may be accompanied by the urge for critical supervision, in line with a positive interpretation of critical democratic citizens (Dalton, 2004; Norris, 1999). For others, the lack of confidence in institutions is part of a withdrawal from engagement (Stoker, 2006; Hay, 2007). Moreover, a consistent group of adolescents — about half of our sample — displayed inactivity in political and social affairs, while being trustful with institutions. Such an orientation suggests that for a substantial part of young people there may not be alienation, but civic and political participation simply hold little relevance in their everyday lives (cf. Dahl et al., 2018; Farthing, 2010).

The analysis found differences among countries in the likelihood of membership in the different groups. Italian and Greek participants were more likely distrustful toward institutions, 
while either politically active or inactive. Their German counterparts, however, had a greater probability of exhibiting trustful engagement. These findings indicate that sociopolitical history, as well as the current political climate and events in different countries might have substantial influence on youths' citizenship orientations. The greater probability of political dissatisfaction in Southern Europe could be related, for example, to the greater impact of the economic crisis (e.g., Bosco \& Verney, 2012; Lima \& Artiles, 2013; Quaranta \& Martini, 2017).

Students who perceived higher social norms favoring participation were less likely unengaged and distrustful, suggesting that peers and family members that encourage participation may be a protective factor inhibiting adolescent political alienation (e.g., Glynn et al., 2009; Šerek \& Machackova, 2015). Family support, in particular, seemed to promote higher participation among the participants.

The findings showed that students from lower school tracks were more likely classified as unengaged distrustful, suggesting that vocation-oriented schools may provide fewer opportunities for political socialization and perpetuate existing social inequalities (Eckstein et al., 2012). Perceived democratic school climate also distinguished between profiles - in particular, greater openness for discussion, fairness and student involvement in decision-making predicted membership in profiles with higher political trust. These results suggest that characteristics of the school as an institution, such as opportunities for open discussions and responsiveness, may induce greater satisfaction and trust toward the larger institutional context (Hahn, 1998), but not necessarily the adoption of more participative citizenship orientations. Student participation in school activities and opportunities for critical reflection, however, was associated with higher involvement, regardless of its trust-oriented stance. Our findings suggest that creating opportunities to participate actively and inviting the consideration and integration of multiple views at school 
support the development of interested and engaged youth who are critically conscious and autonomous as citizens (Fernandes-Jesus et al., 2012; Ferreira et al., 2012; Menezes, 2003).

An interesting finding of the present study is that sense of neighborhood community did not predict adolescent citizenship orientations. Although sense of community is linked to community engagement and participation (Talò et al., 2014), the results can be explained by the theory of sense of community and community responsibility (TSC-R; Nowell \& Boyd, 2010, 2011, 2014; Prati et al., 2020). According to this theory, there are two aspects of community experience: sense of community as a resource for meeting key psychosocial needs and sense of community responsibility (SOC-R; i.e., feelings of obligation to a community). TSC-R posits that an emphasis on community as a resource for meeting one's needs would attenuate the relationship between sense of community and participation, while SOC-R is thought to exhibit a relatively stronger direct effect on community engagement and participation. We recommend that future studies investigate the role of SOC-R in predicting adolescents' participation.

\section{Limitations}

A few limitations of this study should be noted. First, it relied on non-representative national samples. However, the data collection sought to represent a broad variety of national, living and educational conditions, which gives us a certain confidence in the results. Empirical research with wider and representative samples would help confirm our findings and estimate reliably group sizes. Second, examining stability and changes in the identified groupings was beyond the scope of the current study and would have required bigger samples in order to obtain reliable results.

However, further research implementing transition analyses and based on larger longitudinal data is also needed to understand the conditions in which youth transition from one orientation to another in time and in what direction. It should also be noted that the design of the study, while considering time interval, does not allow inferring causal relations among variables. However, the measurement 
of predictors and profile indicators at two distinct times strengthen the conclusions regarding associations by eliminating possible influences related to the moment of compilation. Finally, most contextual variables in this study were measured in terms of individual perception. Additional research could consider multiple sources (parents, teachers, observations, etc.) and the multilevel nature of variables like school climate (e.g., Vieno et al., 2013).

\section{Conclusion}

The study significantly adds to the existing literature, by exploring a new way of classifying citizenship orientations among youth, which were found across a large sample of young people from different European countries (North, South, Central and Eastern Europe). The examination of naturally-occurring groups according to theoretically-driven dimensions of participation, interest and trust may offer a new and stimulating way of understanding the plurality of young people's citizenship and its determinants. Further research could advance our understanding of youth citizenship by including other dimensions of citizen dissatisfaction in characterizing participative orientations, as previous research suggests that principle-driven dissatisfaction could also underline additional distinctions on aspects of democratic engagement (Abdelzadeh \& Ekman, 2012; Abdelzadeh et al., 2015).

Our findings have important implications for the definition and research of citizenship education programs in Europe. It has been argued that what is usually at focus in both policies and monitoring studies is a conception of young citizens as "satisfied democrats" (Zimenkova, 2013, p. 39) and this does not allow space for dissent and critical reflection as educational goals. This study suggests that a great number of students may be in need of further development of their attentive and participative capacities as opposed to their trust in institutions. Moreover, as evidenced, an effective strategy seems to be that of ensuring actual participation in school-based groups or councils and critical reflection over participative activities, in line with an educational approach that 
is based on practice (Biesta, 2011; Lawy \& Biesta, 2006). Knowledge of the different types of citizenship orientations and their specific determinants is therefore of high significance for tailoring adequate activities to youth needs in socialization contexts. 


\section{References}

Abdelzadeh, A., \& Ekman, J. (2012). Understanding critical citizenship and other forms of public dissatisfaction: An alternative framework. Politics, Culture and Socialization, 3(1-2), 177194.

Abdelzadeh, A., Özdemir, M., \& Van Zalk, M. (2015). Dissatisfied citizens: An asset to or a liability on the democratic functioning of society? Scandinavian Political Studies, 38(4), 410436.

Albanesi, C., Cicognani, E., \& Zani, B. (2007). Sense of community, civic engagement and social well-being in Italian adolescents. Journal of Community \& Applied Social Psychology, 17(5), 387-406. http://doi.org/10.1002/casp.903

Allen, L., \& Bang, H. J. (2015). Ecological contexts and youth civic and political engagement in Paris, France. Journal of Applied Developmental Psychology, 39(C), 34-43.

http://doi.org/10.1016/j.appdev.2015.04.010

Amnå, E., \& Ekman, J. (2014). Standby citizens: Diverse faces of political passivity. European Political Science Review, 6(2), 261-281. http://doi.org/10.1017/S175577391300009X

Amnå, E., \& Ekman, J. (2015). Standby citizens. In M. Barrett \& B. Zani (Eds.), Political and Civic Engagement: Multidisciplinary Perspectives (pp. 96-108). London: Routledge.

Amnå, E., Ekström, M., Kerr, M., \& Stattin, H. (2010). Codebook: The political socialization program. Örebro: Youth \& Society at Örebro University, Sweden.

Andolina, M. W., Jenkins, K., Zukin, C., \& Keeter, S. (2003). Habits from home, lessons from school: Influences on youth civic engagement. Political Science and Politics, 36(2), 275-280. http://doi.org/10.1017/S104909650300221X

Asparouhov, T., \& Muthén, B. (2014). Auxiliary variables in mixture modeling: Three-step approaches using Mplus. Structural Equation Modeling: a Multidisciplinary Journal, 21(3), 
329-341. http://doi.org/10.1080/10705511.2014.915181

Atkins, R., \& Hart, D. (2003). Neighborhoods, adults, and the development of civic identity in urban youth. Applied Developmental Science, 7(3), 156-164.

http://doi.org/10.1207/S1532480XADS0703 6

Barrett, M., \& Zani, B. (2015). Political and Civic Engagement: Multidisciplinary Perspectives. London: Routledge.

Biesta, G. (2011). Learning democracy in school and society: Education, lifelong learning and the politics of citizenship. Rotterdam: Sense Publishers.

Bosco, A., \& Verney, S. (2012). Electoral epidemic: The political cost of economic crisis in Southern Europe, 2010-11. South European society and politics, 17(2), 129-154. https://doi.org/10.1080/13608746.2012.747272

Bronfenbrenner, U., \& Morris, P. A. (2007). The bioecological model of human development. In W. Damon and R.M. Lerner (Eds.), Handbook of Child Psychology (pp. 793-828). Hoboken, NJ: John Wiley \& Sons, Inc. http://doi.org/10.1002/9780470147658.chpsy0114

Chiessi, M., Cicognani, E., \& Sonn, C. (2010). Assessing Sense of Community in adolescents: validating the brief scale of Sense of Community in adolescents (SOC-A). Journal of Community Psychology, 38(3), 276-292. http://doi.org/10.1002/jcop.20364

Chupp, M. G., \& Joseph, M. L. (2010). Getting the most out of service learning: Maximizing student, university and community impact. Journal of Community Practice, 18(2-3), 190-212. http://doi.org/10.1080/10705422.2010.487045

Cicognani, E., Noack, P., \& Macek, P. (2020). CATCH-EyoU. Processes in Youth's Construction of Active EU Citizenship. Cross-national Longitudinal (Wave 1 and 2) Questionnaires. EXTRACT. Adolescents' Patterns of Citizenship Orientations in Italy, Sweden, Germany, Greece, Czech Republic [Dataset]. University of Bologna. 
http://doi.org/10.6092/unibo/amsacta/6420

Cicognani, E., \& Zani, B. (2015). Social and psychological factors influencing political and civic participation: A psychological perspective. In M. Barrett \& B. Zani (Eds.), Political and civic engagement: Multidisciplinary perspectives (pp. 124-145). Routledge.

Dahl, V., Amnå, E., Banaji, S., Landberg, M., Šerek, J., Ribeiro, N., Beilmann, M., Pavlopoulos, V., \& Zani, B. (2018). Apathy or alienation? Political passivity among youths across eight European Union countries. European Journal of Developmental Psychology, 15(3), 284-301. https://doi.org/10.1080/17405629.2017.1404985

Dahl, V., Abdelzadeh, A., \& Sohl, S. (2016). The moderating role of political interest: Investigating involvement in institutional and non-institutional political participation among young adults in Sweden. Politics, Culture and Socialization, 7(1-2), 157-182.

Dalton, R. J. (2004). Democratic Challenges, Democratic Choices. Oxford: Oxford University Press. http://doi.org/10.1093/acprof:oso/9780199268436.001.0001

Dalton, R. J., \& Welzel, C. (Eds.). (2014b). The Civic Culture Transformed. New York: Cambridge University Press. http://doi.org/10.1017/CBO9781139600002

Eckstein, K., Noack, P., \& Gniewosz, B. (2012). Attitudes toward political engagement and willingness to participate in politics: Trajectories throughout adolescence. Journal of Adolescence, 35(3), 485-495. http://doi.org/10.1016/j.adolescence.2011.07.002

Ekman, J., \& Amnå, E. (2012). Political participation and civic engagement: Towards a new typology. Human Affairs, 22(3), 283-300. http://doi.org/10.2478/s13374-012-0024-1

Erikson, E. H. (1968). Identity. New York, NY: W. W. Norton \& Company.

Evans, M., \& Stoker, G. (2016). Political participation in Australia: Contingency in the behaviour and attitudes of citizens. Australian Journal of Political Science, 51(2), 272-287.

Farthing, R. (2010). The politics of youthful antipolitics: Representing the "issue" of youth 
participation in politics. Journal of Youth Studies, 13(2), 181-195.

http://doi.org/10.1080/13676260903233696

Fernandes-Jesus, M., Malafaia, C., Ferreira, P., Cicognani, E., \& Menezes, I. (2012). The many faces of Hermes: The quality of participation experiences and political attitudes of migrant and non-migrant youth. Human Affairs, 22(3), 434-447. http://doi.org/10.2478/s13374-012$\underline{0035-y}$

Ferreira, P. D., Azevedo, C. N., \& Menezes, I. (2012). The developmental quality of participation experiences: Beyond the rhetoric that "participation is always good!" Journal of Adolescence, 35(3), 599-610. http://doi.org/10.1016/j.adolescence.2011.09.004

Fischer, A., \& Kohr, H. (2002). Politisches engagement. In A. Glockner-Rist (Ed.), ZUMA Informationssystem. Elektronisches Handbuch Sozialwissenschaftlicher Erhebungsinstrumente. Version 6.00. Mannheim: Zentrum für Umfragen, Methoden und Analysen.

Flanagan, C. A., Cumsille, P., Gill, S., \& Gallay, L. S. (2007). School and community climates and civic commitments: Patterns for ethnic minority and majority students. Journal of Educational Psychology, 99(2), 421-431. http://doi.org/10.1037/0022-0663.99.2.421

Gamson, W. (1968). Power and discontent. Homewood, Illinois: The Dorsey Press.

Geissel, B. (2008). Reflections and findings on the critical citizen: Civic education - What for? European Journal of Political Research, 47, 34-63. http://doi.org/10.1111/j.1475$\underline{6765.2007 .00714 . x}$

Glynn, C. J., Huge, M. E., \& Lunney. C. A. (2009). The Influence of Perceived Social Norms on College Students' Intention to vote. Political Communication, 26(1), 48-64. http://doi.org/10.1080/10584600802622860 Hahn, C. (1998). Becoming Political. Albany, NY: SUNY Press. 
Harris, A., Wyn, J., \& Younes, S. (2010). Beyond apathetic or activist youth. Young, 18(1), 9-32. http://doi.org/10.1177/110330880901800103

Hay, C. (2007). Why We Hate Politics. Cambridge: Polity Press.

Hibbing, J. R., \& Theiss-Morse, E. (2002). Stealth Democracy. Cambridge: Cambridge University Press.

Hooghe, M., \& Marien, S. (2013). A comparative analysis of the relation between political trust and forms of political participation in Europe. European Societies, 15(1), 131-152. https://doi.org/10.1080/14616696.2012.692807

Kelly, D. C. (2006). Parents' influence on youths' civic behaviors: The civic context of the caregiving environment. Families in Society: the Journal of Contemporary Social Services, 87(3), 447-455. http://doi.org/10.1606/1044-3894.3550

Lawy, R. S., \& Biesta, G. J. J. (2006). Citizenship-as-practice: The educational implications of an inclusive and relational understanding of citizenship. British Journal of Educational Studies, 54(1), 34-50. https://doi.org/10.1111/j.1467-8527.2006.00335.x

Lenzi, M., Vieno, A., Pastore, M., \& Santinello, M. (2013). Neighborhood social connectedness and adolescent civic engagement: An integrative model. Journal of Environmental Psychology, 34, 45-54. http://doi.org/10.1016/j.jenvp.2012.12.003

Lenzi, M., Vieno, A., Sharkey, J., Mayworm, A., Scacchi, L., Pastore, M., \& Santinello, M. (2014). How school can teach civic engagement besides civic education: The role of democratic school climate. American Journal of Community Psychology, 54(3-4), 251-261. http://doi.org/10.1007/s10464-014-9669-8

Lima, M. D. P. C., \& Artiles, A. M. (2013). Youth voice (s) in EU countries and social movements in southern Europe. Transfer: European Review of Labour and Research, 19(3), 345-364. https://doi.org/10.1177/1024258913493732 
Loader, B. D., Vromen, A., \& Xenos, M. A. (2014). The networked young citizen: social media, political participation and civic engagement. Information, Communication \& Society, 17(2), 143-150. http://doi.org/10.1080/1369118X.2013.871571

Menezes, I. (2003). Participation experiences and civic concepts, attitudes and engagement: Implications for citizenship education projects. European Educational Research Journal, 2(3), 430-445. http://doi.org/10.2304/eerj.2003.2.3.8

Muthén, L. K., \& Muthén, B. O. (2015). Mplus User's Guide (7 ed.). Los Angeles, CA: Muthén \& Muthén. Retrieved from https://www.statmodel.com/html_ug.shtml

Norris, P. (Ed.). (1999). Critical Citizens. Oxford: Oxford University Press.

Nowell, B., \& Boyd, N. M. (2010). Viewing community as responsibility as well as resource: Deconstructing the theoretical roots of psychological sense of community. Journal of Community Psychology, 38(7), 828-841. http://doi.org/10.1002/jcop.20398

Nowell, B., \& Boyd, N. M. (2011). Sense of community as construct and theory: Authors' response to McMillan. Journal of Community Psychology, 39(8), 889-893. http://doi.org/10.1002/jcop.20504

Nowell, B., \& Boyd, N. M. (2014). Sense of community responsibility in community collaboratives: Advancing a theory of community as resource and responsibility. American Journal of Community Psychology, 54(3-4), 229-242. http://doi.org/10.1007/s10464-014$\underline{9667-\mathrm{x}}$

Nylund, K. L., Asparouhov, T., \& Muthén, B. O. (2007). Deciding on the number of classes in latent class analysis and growth mixture modeling: A Monte Carlo simulation study. Structural Equation Modeling: A Multidisciplinary Journal, 14(4), 535-569. http://doi.org/10.1080/10705510701575396

Nylund-Gibson, K., \& Choi, A. Y. (2018). Ten frequently asked questions about latent class This item was downloaded from IRIS Università di Bologna (https://cris.unibo.it/) 
analysis. Translational Issues in Psychological Science, 4(4), 440. https://doi.org/10.1037/tps0000176

Podsakoff, P. M., MacKenzie, S. B., \& Podsakoff, N. P. (2012). Sources of method bias in social science research and recommendations on how to control it. Annual Review of Psychology, 63, 539-569. https://doi.org/10.1146/annurev-psych-120710-100452

Prati, G., Procentese, F., Albanesi, C., Cicognani, E., Fedi, A., Gatti, F., Mannarini, T., Rochira, A., Tartaglia, S., Boyd, N., Nowell, B., \& Gattino, S. (2020). Psychometric properties of the Italian version of the sense of community responsibility scale. Journal of Community Psychology. Advance online publication. https://doi.org/10.1002/jcop.22366

Prior, M. (2010). You've either got it or you don't? The stability of political interest over the life cycle. The Journal of Politics, 72(3), 747-766. https://doi.org/10.1017/S0022381610000149

Quaranta, M., \& Martini, S. (2017). Easy come, easy go? Economic performance and satisfaction with democracy in Southern Europe in the last three decades. Social Indicators Research, 131(2), 659-680. http://doi.org/10.1007\%2Fs11205-016-1270-0

Quintelier, E., \& Hooghe, M. (2013). The relationship between political participation intentions of adolescents and a participatory democratic climate at school in 35 countries. Oxford Review of Education, 39(5), 567-589. http://doi.org/10.1080/03054985.2013.830097

Quintelier, E., Stolle, D., \& Harell, A. (2012). Politics in peer groups: Exploring the causal relationship between network diversity and political participation. Political Research Quarterly, 65(4), 868-881. http://doi.org/10.1177/1065912911411099

Rosanvallon, P. (2008). Counter-Democracy. Cambridge: Cambridge University Press.

Roschelle, A. R., Turpin, J., \& Elias, R. (2000). Who learns from Service Learning? American Behavioral Scientist, 43(5), 839-847. http://doi.org/10.1177/00027640021955630

Rossi, G., Lenzi, M., Sharkey, J. D., Vieno, A., \& Santinello, M. (2016). Factors associated with This item was downloaded from IRIS Università di Bologna (https://cris.unibo.it/) 
civic engagement in adolescence: The effects of neighborhood, school, family, and peer contexts. Journal of Community Psychology, 44(8), 1040-1058.

http://doi.org/10.1002/jcop.21826

Russo, S., \& Stattin, H. (2017). Stability and change in youths' political interest. Social Indicators Research, 1, 1-16. https://doi.org/10.1007/s11205-016-1302-9

Schudson, M. (1996). What if civic life didn't die? American Prospect, 25, 17-20.

Schudson, M. (2006). The Varieties of Civic Experience. Citizenship Studies, 10(5), 591-606. http://doi.org/10.1080/13621020600955033

Schulz, W., Ainley, J., Fraillon, J., Kerr, D., \& Losito, B. (2010). ICCS 2009 international report: Civic knowledge, attitudes, and engagement among lower-secondary school students in 38 countries. Amsterdam: International Association for the Evaluation of Educational Achievement (IEA).

Sears, D. O. \& Levy, S. (2003). Childhood and adult political development. In D. O. Sears, L. Huddy \& R. Jervis (Eds.), Oxford Handbook of Political Psychology (pp. 60-109). New York, NY: Oxford University Press.

Šerek, J., \& Machackova, H. (2015). Predicting Online and Offline Civic Participation among Young Czech Roma: The Roles of Resources, Community Perceptions and Social Norms. Journal of Ethnic and Migration Studies, 41(13), 2173-2191.

https://doi.org/10.1080/1369183X.2015.1049590

Silbiger, S. L. (1977). Peers and political socialization. In S. A. Renshon (Ed.) Handbook of Political Socialization (pp. 172-189). New York: Free Press.

Stoker, G. (2006). Why Politics Matters: Making Democracy Work. Basingstoke: Palgrave Macmillan.

Talò, C., Mannarini, T., \& Rochira, A. (2014). Sense of community and community participation: A This item was downloaded from IRIS Università di Bologna (https://cris.unibo.it/) 
meta-analytic review. Social Indicators Research, 117(1), 1-28. http://doi.org/10.1007/s11205-013-0347-2

Torcal, M., \& Montero, J.R. (Eds.) (2006). Political Disaffection in Contemporary Democracies: Social Capital, Institutions, and Politics. London: Routledge.

Torney-Purta, J. (2002). The school's role in developing civic engagement: A study of adolescents in twenty-eight countries. Applied Developmental Science, 6(4), 203-212. http://doi.org/10.1207/s1532480xads0604_7

Torsheim, T., Wold, B., \& Samdal, O. (2000). The Teacher and Classmate Support Scale. School Psychology International, 21(2), 195-212. http://doi.org/10.1177/0143034300212006

Tyler, T. R., \& Smith, H. J. (1999). Justice, social identity and group processes. In T.R. Tyler, R.M. Kramer, and O.J. John (Eds.), The Psychology of the Social Self (pp. 223-263). New York/Hove: Psychology Press.

Tzankova, I. (2018). Youth civic and political (dis)engagement: Representations, patterns and contexts [doctoral dissertation]. AMS Tesi di Dottorato Institutional Doctoral Theses. http://doi.org/10.6092/unibo/amsdottorato/8677

Youniss, J., Bales, S., Christmas-Best, V., Diversi, M., McLaughlin, M., \& Silbereisen, R. (2002). Youth civic engagement in the twenty-first century. Journal of Research on Adolescence, 12(1), 121-148. http://doi.org/10.1111/1532-7795.00027

Vermunt, J. K. (2010). Latent class modeling with covariates: Two improved three-step approaches. Political Analysis, 18, 450-469. http://doi.org/10.1093/pan/mpq025

Vieno, A., Lenzi, M., \& Santinello, M. (2013). Sense of community, unfairness, and psychosomatic symptoms: A multilevel analysis of Italian schools. Journal of Adolescent Health, 53, 142145.

Vieno, A., Perkins, D. D., Smith, T. M., \& Santinello, M. (2005). Democratic school climate and This item was downloaded from IRIS Università di Bologna (https://cris.unibo.it/) 
sense of community in school: A multilevel analysis. American Journal of Community Psychology, 36(3-4), 327-341. http://doi.org/10.1007/s10464-005-8629-8

Walsh, L., Black, R., \& Prosser, H. (2018). Young people's perceptions of power and influence as a basis for understanding contemporary citizenship. Journal of Youth Studies, 21(2), 218-234. https://doi.org/10.1080/13676261.2017.1363388

Wanders, F., Dijkstra, A. B., Maslowski, R., van der Veen, I., \& Amnå, E. (2020). The role of teachers, parents, and friends in developing adolescents' societal interest. Scandinavian Journal of Educational Research, 1-16. Advance online publication. https://doi.org/10.1080/00313831.2020.1754901

Wilkenfeld, B., Lauckhardt, J. \& Torney-Purta, J. (2010). The relation between developmental theory and measures of civic engagement in research on adolescents. In L. R. Sherrod, J. Torney-Purta \& C. A. Flanagan (Eds.), Handbook of Research on Civic Engagement in Youth (pp. 193-219). Hoboken: Wiley.

Zaff, J. F., Malanchuk, O., \& Eccles, J. S. (2008). Predicting positive citizenship from adolescence to young adulthood: The effects of a civic context. Applied Developmental Science, 12(1), 38-53. http://doi.org/10.1080/10888690801910567

Zimenkova, T. (2013). Active citizenship as harmonious co-existence? About the political in participatory education. In R. Hedtke and T. Zimenkova (Eds.), Education for Civic and Political Participation (pp. 36-53). New York: Routledge.

Zukin, C., Keeter, S., Andolina, M., Jenkins, K., \& Carpini, M. X. D. (2006). A New Engagement? Oxford: Oxford University Press. 
Table 1.

Descriptive Statistics and Intercorrelations

\begin{tabular}{|c|c|c|c|c|c|c|c|c|c|c|c|c|}
\hline & $N$ & $\begin{array}{r}\text { Min- } \\
\text { Max }\end{array}$ & $\begin{array}{c}M \\
(S D)\end{array}$ & $\begin{array}{r}\text { Skew } \\
\text { ness }\end{array}$ & 1 & 2 & 3 & 4 & 5 & 6 & 7 & 8 \\
\hline $\begin{array}{l}\text { 1. Civic and } \\
\text { political } \\
\text { participation (T2) }\end{array}$ & 1907 & $\begin{array}{l}1- \\
4.5\end{array}$ & $\begin{array}{c}1.39 \\
(0.41)\end{array}$ & 2.43 & & & & & & & & \\
\hline $\begin{array}{l}\text { 2. Sociopolitical } \\
\text { interest (T2) }\end{array}$ & 1902 & $1-5$ & $\begin{array}{c}2.91 \\
(0.83)\end{array}$ & 0.00 & $.32^{* *}$ & & & & & & & \\
\hline $\begin{array}{l}\text { 3. Political trust } \\
\text { (T2) }\end{array}$ & 1911 & $1-5$ & $\begin{array}{c}2.79 \\
(0.82)\end{array}$ & -0.09 & -.03 & $.16^{* *}$ & & & & & & \\
\hline $\begin{array}{l}\text { 4. Democratic } \\
\text { school climate } \\
\text { (T1) }\end{array}$ & 1901 & $1-5$ & $\begin{array}{c}3.32 \\
(0.79)\end{array}$ & -0.45 & -.01 & $.12^{* *}$ & $.21^{* *}$ & & & & & \\
\hline $\begin{array}{l}\text { 5. School quality } \\
\text { of participation } \\
\text { (T1) }\end{array}$ & 1893 & $1-5$ & $\begin{array}{c}3.42 \\
(0.73)\end{array}$ & -0.62 & $.12^{* *}$ & $.21^{* *}$ & .04 & $.40^{* *}$ & & & & \\
\hline $\begin{array}{l}\text { 6. Student } \\
\text { participation (T1) }\end{array}$ & 1889 & $0-3$ & $\begin{array}{c}0.85 \\
(0.93)\end{array}$ & 0.80 & $.24^{* *}$ & $.15^{* *}$ & $-.11^{* *}$ & .00 & $.15^{* *}$ & & & \\
\hline $\begin{array}{l}\text { 7. Sense of } \\
\text { neighborhood } \\
\text { community (T1) }\end{array}$ & 1880 & $1-5$ & $\begin{array}{c}2.92 \\
(0.87)\end{array}$ & -0.20 & $.09^{* *}$ & $.13^{* *}$ & $.15^{* *}$ & $.21^{* *}$ & $.19^{* *}$ & $.09^{* *}$ & & \\
\hline $\begin{array}{l}\text { 8. Peer norms of } \\
\text { participation (T1) }\end{array}$ & 1855 & $1-5$ & $\begin{array}{c}2.64 \\
(0.80)\end{array}$ & -0.10 & $.12^{* *}$ & $.14^{* *}$ & $.15^{* *}$ & $.09^{* *}$ & $.17^{* *}$ & $.06^{*}$ & $.17^{* *}$ & \\
\hline $\begin{array}{l}\text { 9. Family norms } \\
\text { of participation } \\
\text { (T1) }\end{array}$ & 1854 & $1-5$ & $\begin{array}{c}2.82 \\
(0.87)\end{array}$ & -0.15 & $.13^{* *}$ & $.17^{* *}$ & $.12^{* *}$ & $.09^{* *}$ & $.17^{* *}$ & $.11^{* *}$ & $.15^{* *}$ & $.56^{* *}$ \\
\hline
\end{tabular}


Table 2.

Model and Fit Statistics

\begin{tabular}{ccccccc}
\hline K-class & Parameters & LL & BIC & $\begin{array}{c}\text { LMR } \\
(p)\end{array}$ & $\begin{array}{c}\text { BLRT } \\
(p)\end{array}$ & Entropy \\
\hline 1 & 4 & -6190.31 & 12410.85 & - & - & - \\
2 & 8 & -6022.43 & 12105.32 & $<.001$ & $<.001$ & .48 \\
3 & 12 & -5861.33 & 11813.35 & $<.001$ & $<.001$ & .61 \\
4 & 16 & -5738.18 & 11597.28 & $<.001$ & $<.001$ & .67 \\
5 & 20 & -5681.90 & 11514.94 & .287 & $<.001$ & .72 \\
6 & 24 & -5613.21 & 11407.79 & .009 & $<.001$ & .71 \\
7 & 28 & -5543.79 & 11299.17 & .382 & $<.001$ & .75 \\
8 & 32 & -5500.22 & 11242.27 & .432 & $<.001$ & .72 \\
\hline
\end{tabular}

This item was downloaded from IRIS Università di Bologna (https://cris.unibo.it/) 
Table 3.

Demographic and Contextual Correlates: Multinomial Logistic Regression Results (Odds Ratios)

\begin{tabular}{|c|c|c|c|c|c|c|}
\hline & $\begin{array}{c}\text { Engaged } \\
\text { Trustful } \\
\text { vs. } \\
\text { Unengaged } \\
\text { Trustful }\end{array}$ & $\begin{array}{c}\text { Engaged } \\
\text { Distrustful } \\
\text { vs. } \\
\text { Unengaged } \\
\text { Trustful }\end{array}$ & $\begin{array}{c}\text { Unengaged } \\
\text { Distrustful } \\
\text { vs. } \\
\text { Unengaged } \\
\text { Trustful }\end{array}$ & $\begin{array}{c}\text { Engaged } \\
\text { Trustful vs. } \\
\text { Unengaged } \\
\text { Distrustful }\end{array}$ & $\begin{array}{c}\text { Engaged } \\
\text { Distrustful } \\
\text { vs. } \\
\text { Unengaged } \\
\text { Distrustful }\end{array}$ & $\begin{array}{c}\text { Engaged } \\
\text { Distrustful } \\
\text { vs. } \\
\text { Engaged } \\
\text { Trustful }\end{array}$ \\
\hline Country $^{\mathrm{a}}$ : Italy & $0.38^{*}$ & 1.57 & $2.64^{* *}$ & $0.14^{* * *}$ & 0.60 & $4.13^{* *}$ \\
\hline Country ${ }^{\mathrm{a}}$ : Sweden & 0.47 & 0.05 & 0.63 & 0.75 & 0.08 & 0.10 \\
\hline Country $^{\mathrm{a}}$ : Germany & $2.36^{*}$ & 2.10 & 0.33 & $7.19^{* *}$ & $6.39^{*}$ & 0.89 \\
\hline Country $^{\mathrm{a}}$ : Greece & 1.84 & $20.25^{* * *}$ & $8.31^{* * *}$ & $0.22^{* *}$ & $2.44^{*}$ & $11.02^{* * *}$ \\
\hline Gender: Male & $2.05^{* *}$ & $1.57^{*}$ & $1.61^{*}$ & 1.27 & 0.97 & 0.76 \\
\hline Income & 1.36 & 0.81 & $0.66^{* *}$ & $2.08^{* *}$ & 1.24 & 0.60 \\
\hline Parental education & 1.24 & 1.08 & 0.87 & 1.42 & 1.24 & 0.87 \\
\hline Migration & & & & & & \\
\hline $\begin{array}{l}\text { background: } \\
\text { Non-migrant }\end{array}$ & 1.17 & 1.03 & 0.78 & 1.51 & 1.33 & 0.88 \\
\hline $\begin{array}{l}\text { School track: } \\
\text { Higher }\end{array}$ & 1.05 & 0.63 & $0.34^{* * *}$ & $3.14^{* *}$ & 1.88 & 0.60 \\
\hline Democratic climate & 1.11 & $0.54^{* * *}$ & $0.67^{*}$ & $1.65^{*}$ & 0.80 & $0.49^{* *}$ \\
\hline $\begin{array}{l}\text { Quality of } \\
\text { participation }\end{array}$ & $1.86^{* *}$ & $1.57^{*}$ & 1.04 & $1.79^{*}$ & 1.51 & 0.84 \\
\hline $\begin{array}{l}\text { Student } \\
\text { participation }\end{array}$ & $1.60^{* *}$ & $1.40^{* *}$ & 0.96 & $1.66^{* *}$ & $1.45^{* *}$ & 0.88 \\
\hline $\begin{array}{l}\text { Sense of } \\
\text { community }\end{array}$ & 0.89 & 0.89 & 0.83 & 1.07 & 1.06 & 0.99 \\
\hline Peer norms & 1.30 & 1.01 & $0.73^{*}$ & $1.79^{*}$ & 1.39 & 0.78 \\
\hline
\end{tabular}


$\begin{array}{lllllll}\text { Family norms } & 1.80^{* *} & 1.30 & 0.79 & 2.27^{* * *} & 1.65^{* *} & 0.72\end{array}$

Notes. Odds ratios: values closer to 1 indicate no effect of the predictor, values greater than 1

indicate increase of the odds of membership in the outcome category, values lower than 1 indicate decrease of the odds of membership.

${ }^{\mathrm{a} C z e c h ~ R e p u b l i c ~ i s ~ t h e ~ r e f e r e n c e ~ g r o u p ~ f o r ~ t h e ~ v a r i a b l e ~ C o u n t r y . ~}$

${ }^{*} p<.05 ;{ }^{* *} p<.01 ;{ }^{* * *} p<.001$ 


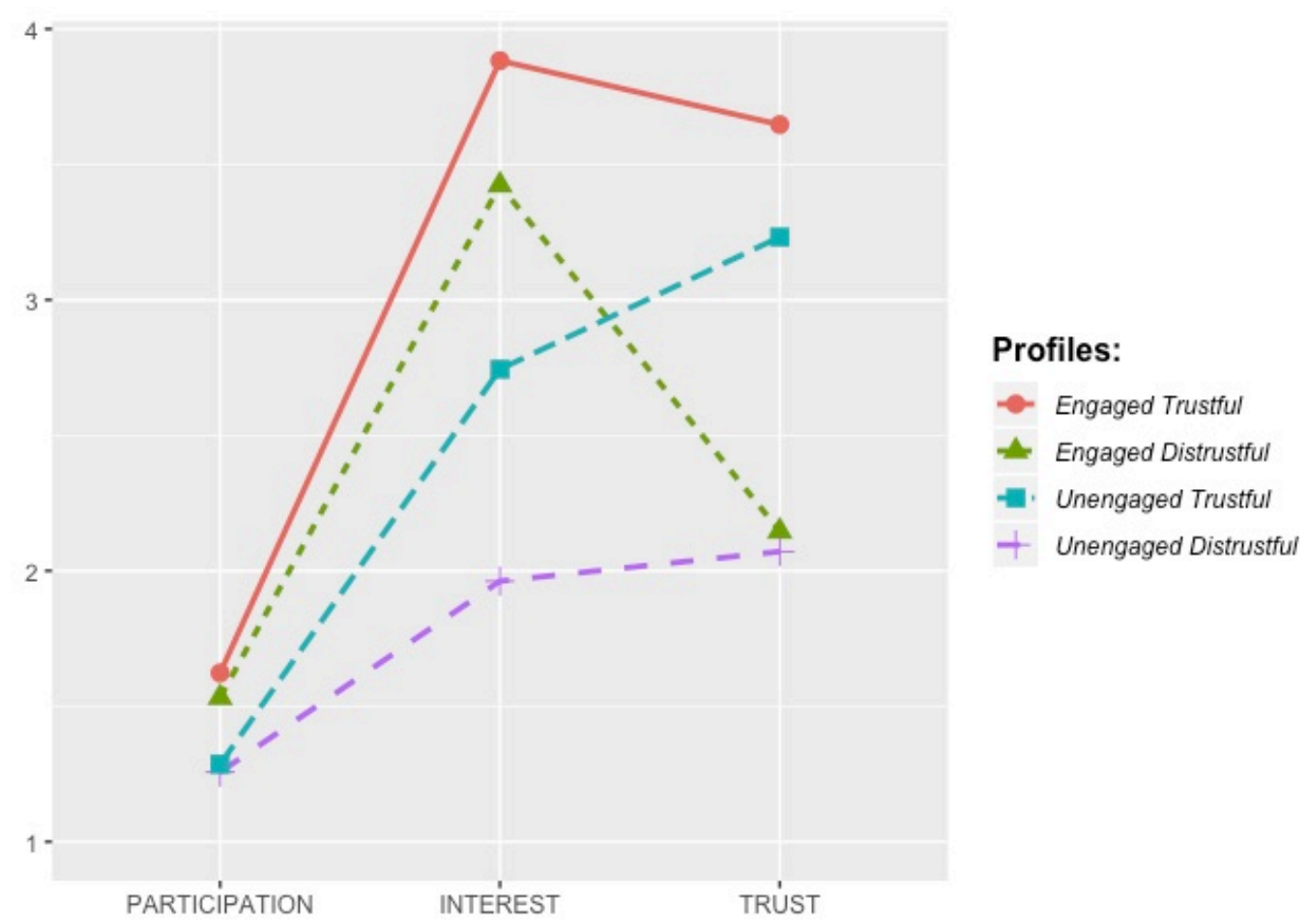

Figure 1. Profiles of citizenship orientations at Time 2 